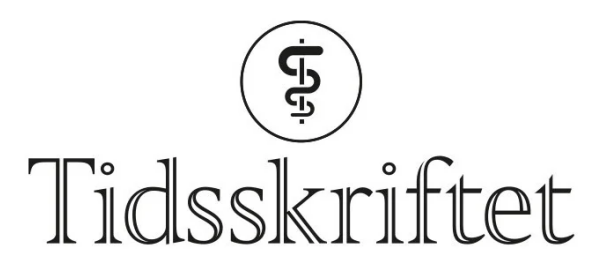

DEN NORSKE LEGEFORENING

\title{
B. Bringedal svarer
}

\author{
KOMMENTAR
}

\section{BERIT BRINGEDAL}

berit.bringedal@legeforeningen.no

Berit Bringedal er sosiolog, PhD og seniorforsker ved Legeforskningsinstituttet (LEFO).

Forfatteren har ikke oppgitt noen interessekonflikter.

Takk for en viktig kommentar. Jeg er enig i at påstanden er for kategorisk. Kommentaren gir meg anledning til å nyansere.

I en studie av sykefraværet i befolkningen i 2006 (1) sammenlignet vi fordelingen av lette og diffuse psykiatriske diagnoser med diffuse muskel- og skjelettdiagnoser. Antakelsen var at dette er sykdommer som kan være vanskelig å skille fra hverandre, og vi var interessert i om det var systematikk i hvilke yrkesgrupper som hadde hvilken diagnose. Resultatet var klart: høy utdannelse økte signifikant sannsynligheten for en psykiatrisk diagnose sammenlignet med en diffus muskel- skjelettdiagnose. Vi så for eksempel at høyt utdannet helsepersonell svært sjelden hadde en diffus muskel-skjelettdiagnose som årsak til sykefravær, mens ufaglærte arbeidere i industrien svært sjelden hadde en diffus psykiatrisk diagnose.

Dette funnet tolket vi som et eksempel på at jo mer diffus sykdommen er, desto større er innflytelsen av sosiale og kulturelle faktorer i diagnosesettingen. Det er selvsagt stor forskjell på diffuse symptomer og symptomer som er mer entydige. En lite diffus muskelskjelettsykdom, som et beinbrudd, gir selvsagt ikke rom for sosiokulturell fortolkning. Hensikten med spissformuleringen var å få frem at de tolkninger som gjøres av symptomer også kan påvirkes av sosiale og kulturelle faktorer, og dermed at medisinsk praksis ikke utelukkende er basert på objektiv vitenskap. Selv om å streve mot objektiv og presis diagnostikk er avgjørende for god behandling, er det også viktig at leger anerkjenner innslaget av sosiale og kulturelle faktorer som påvirker det som skjer i helsetjenesten.

\section{LITTERATUR}

1. Bringedal B, Tufte PA. Social and diagnostic inequality in health. Scand J Public Health 2012; 40: 65662. [PubMed][CrossRef]

Publisert: 22. februar 2021. Tidsskr Nor Legeforen. DOI: 10.4045/tidsskr.21.0082

(C) Tidsskrift for Den norske legeforening 2023. Lastet ned fra tidsskriftet.no 26. april 2023. 